\title{
Variation of Slab Component in Ancient and Modern Merapi Products: A Detailed Look into Slab Derived Fluid Fluctuation over the Living Span of One of the Most Active Volcanoes in Sunda Arc
}

\author{
Esti Handini ${ }^{* 1}$, Toshiaki Hasenaka ${ }^{1}$, Agung Harijoko ${ }^{2}$, and Yasushi Mori ${ }^{3}$ \\ ${ }^{1}$ Kumamoto University, 2-39-1 Kurokami, Chuo-ku, Kumamoto-shi, 860-8555, Japan \\ ${ }^{2}$ Department of Geological Engineering, Faculty of Engineering, Gadjah Mada University, Yogyakarta, Indonesia \\ ${ }^{3}$ Kitakyushu Museum of Natural History and Human History, 2-4-1 Higashida, Yahatahigashi-ku, Kitakyushu, \\ 805-0071, Japan
}

\begin{abstract}
Holocene eruptions of Merapi have produced both medium-K and high-K calc alkaline series which correspond to products older and younger than 1900 years respectively. The change has been attributed to increasing sediment input as the volcano matures. This study presents two Merapi samples which represent Ancient and Modern Merapi. The two samples are analyzed for subduction components including B, Ba, $\mathrm{Sr}$, and $\mathrm{Pb}$ using $\mathrm{X}$-ray fluorescence (XRF) spectrometer and prompt gamma ray analysis (PGA). Our finding shows that Ancient Merapi sample from Plawangan Hill lava is close in affinities with younger than 1900 years high-K magma series. On the other hand, Modern Merapi sample from 2006 eruption juvenile is plotted within medium-K magma series which are observed in eruption products older than 1900 years. Ratios of fluid mobile elements to high field strength element (HFSE) (i.e. B/ Nb, $\mathrm{Ba} / \mathrm{Y}, \mathrm{Pb} / \mathrm{Nb}$ ) consistently show that Ancient Merapi sample has higher input of slab derived fluid than Modern Merapi sample. A model using $\mathrm{B} / \mathrm{Nb}$ and $\mathrm{Ba} / \mathrm{Nb}$ suggests that Plawangan magma requires $1.5 \%$ of sediment derived fluid, higher than estimated in 2006 eruption magma $(1.2 \%)$ and medium-K series magma, and within the range of high-K series magma, to explain its slab component enrichment. This evidence suggests that slab derived component addition to the sub-arc mantle wedge highly fluctuates over short period of evolution of a volcano. One possible explanation is the presence of veined hydrous metasomatized sub-arc mantle as Merapi magma source which allows melting of different mantle area to produce fluctuation of slab components in the course of evolution of Merapi magmas.
\end{abstract}

Keywords: Boron - Slab component - Slab derived fluid contribution · Ancient and Modern Merapi · Sunda arc.

\section{INTRODUCTION}

Minor addition of fluids from subducting slab to the mantle wedge, either from altered oceanic crust (AOC) or from its overlying sediment (SED) or both, has been considered as an important factor that shapes geochemical characteristics of arc magmas (Whitford and Jezek, 1982; Tera et al., 1986; Vroon et al., 1993, 2001; Ishikawa and Nakamura, 1994; Turner and Fo-

\footnotetext{
${ }^{*}$ Corresponding author: E. HANDINI, Kumamoto University, 2-39-1 Kurokami, Chuo-ku, Kumamoto-shi, 8608555, Japan. E-mail: estihandini@gmail.com
}

den, 2001; Gertisser and Keller, 2003a,b; Hanyu et al., 2012). Slab components are elements that are transferred from the slab to the mantle wedge during slab dehydration and/or melting in some cases (Pearce et al., 2005; Hanyu et al., 2012). Some of these elements have high mobility in fluid and extensively partition into the fluid phase during dehydration of both AOC and SED. Consequently, fluid mobile element such as $\mathrm{B}, \mathrm{Ba}, \mathrm{Pb}$, and $\mathrm{Sr}$ is strongly partitioned into the fluid phase in equilibrium with the dehydrated slab (Moran et al., 1992; Bebout et al., 
1999; Sano et al., 2001). Elliott (2003) suggests that $\mathrm{Pb}$, for example, is abundant in marine SED, while $\mathrm{Ba}$ and $\mathrm{Sr}$ are abundant in AOC. Boron is specifically abundant in subducting SED more than in AOC (Morris et al., 1990; Ishikawa and Nakamura, 1993; Ishikawa and Nakamura, 1994; Ryan et al., 1995; Smith et al., 1995; Sano et al., 2001). Accordingly, slab component is a convenient proxy to evaluate slab derived fluid contribution to the mantle wedge in a magmatic arc.

Previous studies have suggested that Holocene eruptions of Merapi have produced both medium-K and high-K calc alkaline series (Andreastuti, 1999; Gertisser and Keller, 2003a,b). Furthermore, Gertisser and Keller (2003b) recognize that the medium-K series corresponds to samples older than 1900 years, while the high-K series corresponds to samples younger than 1900 years. They suggest that the older than 1900 years medium-K magma series requires less input from subducting sediment than the younger than 1900 years high-K magma series. This result implies that subducting sediment input increases as the volcano matures.

This study focuses on two samples whose ages are well defined. One sample is taken from Plawangan Hill lava which represents Ancient Merapi while the other sample is a juvenile of 2006 pyroclastic flow deposit which represents Modern Merapi. The finding of this study shows that Ancient Merapi sample is plotted in high-K calc-alkaline field which corresponds to eruption products younger than 1900 years. On the other hand, Modern Merapi sample is plotted within the medium-K calc-alkaline magma series which corresponds to eruption products older than 1900 years. The two samples provide estimation of how slab component changes in a wide span of evolution of a volcano in an island arc setting. Our findings suggest that slab derived fluid contributions highly fluctuate and change of slab input at a same level of Wadati -Benioff zone appears to be more frequent than it is thought. This rate of changes in slab components can be explained using veined mantle model where slab-derived component is concentrated in veins in the hydrous metasomatized mantle. Partial melt of different area of this veined mantle may produce Ancient and Modern Merapi magmas which show rapid fluctuation of slab components.

\section{Geology of Merapi Volcano}

Merapi is the Quaternary volcanic front of central section of Sunda arc, Java Island, Indonesia, and corresponds to $180 \mathrm{~km}$ depth of Wadati Benioff zone. This volcano, dubbed as the most active volcano in Indonesia, has erupted a wide range of magma compositions.

History of Merapi volcano can be summarized into four stages. The earliest activity of Merapi was thought to be Gunung Bibi, lies in the NNE of modern edifice of Merapi. Bhertommier (1990) and Camus et al. (2000) suggest that K-Ar age of a lava flow from this PreMerapi is $0.67 \pm 0.25$ Ma. This stage is thought to be Pre-Merapi activities. Many consider that the first stage of Merapi volcanism is Proto Merapi or Ancient Merapi which is represented by Turgo-Plawangan Hills in the south of Merapi (Berthommier, 1990; Newhall et al., 2000; Camus et al., 2000). This stage is thought to have begun 40000 yBP. The K-Ar age measurement of Plawangan Hill lava is dated to $135 \pm 3 \mathrm{ka}$ (Gertisser et al., 2012). Middle Merapi period or Old Merapi is the second stage of Merapi volcanism. This period is represented by Batulawang and Gadjah Mungkur (Bahar, 1984) which mainly produced scoria flow or St. Vincent-type nueeds ardentes (Camus et al., 2000). Bhertommier (1990) suggests that Kukusan fault is a remnant of an avalanche caldera. Several ${ }^{14} \mathrm{C}$ dating results suggest that this stage may have started at $9630 \pm 60 \mathrm{yBp}$ (Newhall et al., 2000) or older $11792 \pm 90$ yBP (Gertisser, 2001). The third stage, Recent Merapi period, is thought to have started at approximately $2220 \mathrm{yBP}$ and some of its last eruptions are recorded in $15^{\text {th }}$ century (Camus et al., 2000). The fourth stage is Modern Merapi period which first recorded eruption was in $17^{\text {th }}$ century (van Boekhold, 1972; Camus et al., 2000). This period is indicated by episodes of dome growth and collapse throughout its history. Many reports detail the 2006 eruption event (Charbonnier and Gertisser, 2008; Ratdomopurbo et al., 2013). This eruption is a classic example of Modern Merapi which is characterized by Merapi type eruption which produces dome collapse pyroclastic flow. 


\section{SAMPLE AND METHOD}

The two samples in this study are presented in Table 1. Sample M01 is a lava flow from Plawangan Hill, representing Ancient Merapi. Sample M19 is a juvenile of June 2006 pyroclastic flow (Figure 1). Lava and pyroclastic samples from Holocene Merapi reported by Gertisser and Keller (2003b) are also used for comparison. In order to minimize the uncertainty of different measurements between analyzed and published samples, standard error of sample is presented as error bars in Figure 3, Figure 4, and Figure 5. The standard error $(S E)$ is calculated using formula $S E=S D / \sqrt{ }(N)$, where $S D$ is standard deviation and $N$ is the number of measurements.

Major and trace elements of the two samples were determined with a Philips PANalytical MagiX PRO XRF spectrometer using 1:5 dilution glass beads at the Kitakyushu $\mathrm{Mu}$ seum of Natural History and Human History, following the calibration method of Mori and Mashima (2005). Boron concentration is analyzed by prompt gamma ray (PGA) analysis at the thermal neutron beam guide JRR-3M reactor using the facility described in Yonezawa et al. (1992) and Yonezawa and Wood (1995), at the Japan Atomic Energy Agency (JAEA) laboratories, following the method explained in Sano et al. $(1999,2004)$.

\section{Results}

\section{Petrography}

Sample from Plawangan lava (M01) is basalt. In thin section, this sample shows porphyritic texture. Plagioclase is present as the main phenocryst phase, followed by clinopyroxene and olivine phenocrysts, mounted in groundmass composed of minute crystals of clinopyroxene, plagioclase, and Fe-Ti oxide. Zoning is common in plagioclase phenocryst. This phenocryst mostly shows resorbed interior and has clinopyroxene rim (Figure 2a). Olivine shows mild alteration to iddingsite along its cracks and rim.

Sample from 2006 eruption is a juvenile fragment of a pyroclastic flow deposit and is basaltic andesite in composition. The hand sample shows porphyrictic texture and is rich in visible plagioclase. Thin section shows that plagioclase is the predominant phenocryst phase
Table 1: Major and trace elements of analyzed samples.

\begin{tabular}{|c|c|c|}
\hline $\begin{array}{l}\text { Sample } \\
\text { ID }\end{array}$ & $\begin{array}{c}\text { M01 } \\
\text { Plawangan }\end{array}$ & $\begin{array}{c}\text { M19 } \\
2006 \text { PFJ }^{*}\end{array}$ \\
\hline \multicolumn{3}{|c|}{ Major element (wt.\%) } \\
\hline $\mathrm{SiO}_{2}$ & 49.71 & 54.88 \\
\hline $\mathrm{TiO}_{2}$ & 0.89 & 0.78 \\
\hline $\mathrm{Al}_{2} \mathrm{O}_{3}$ & 19.05 & 18.61 \\
\hline $\mathrm{Fe}_{2} \mathrm{O}_{3}$ & 10.07 & 8.41 \\
\hline $\mathrm{MnO}$ & 0.17 & 0.16 \\
\hline $\mathrm{MgO}$ & 4.47 & 2.93 \\
\hline $\mathrm{CaO}$ & 9.99 & 7.93 \\
\hline $\mathrm{Na}_{2} \mathrm{O}$ & 2.92 & 3.46 \\
\hline $\mathrm{K}_{2} \mathrm{O}$ & 1.59 & 1.71 \\
\hline $\mathrm{P}_{2} \mathrm{O}_{5}$ & 0.2 & 0.24 \\
\hline Total & 99.06 & 99.12 \\
\hline \multicolumn{3}{|c|}{ Trace element (ppm) } \\
\hline Sc & 24 & 14 \\
\hline V & 336 & 213 \\
\hline $\mathrm{Ni}$ & 27 & 3 \\
\hline $\mathrm{Cu}$ & 143 & 28 \\
\hline $\mathrm{Zn}$ & 79 & 79 \\
\hline $\mathrm{Rb}$ & 25 & 38 \\
\hline $\mathrm{Sr}$ & 535 & 531 \\
\hline Y & 22 & 22 \\
\hline $\mathrm{Zr}$ & 65 & 139 \\
\hline $\mathrm{Nb}$ & 2.02 & 5.09 \\
\hline $\mathrm{Ba}$ & 481 & 406 \\
\hline $\mathrm{La}$ & 10 & 15 \\
\hline $\mathrm{Ce}$ & 32 & 45 \\
\hline Hf & 1.86 & 3.3 \\
\hline Ta & 0.15 & 0.37 \\
\hline Th & 29 & 7 \\
\hline $\mathrm{Nd}$ & 11 & 14 \\
\hline $\mathrm{Pb}$ & 19 & 18 \\
\hline $\mathrm{B}^{* *}$ & 14.52 & 20.4 \\
\hline $\mathrm{Sm}^{* *}$ & 5.79 & 4.62 \\
\hline
\end{tabular}

${ }^{*}$ PFJ stands for pyroclastic flow juvenile.

** Analyzed using PGA.

in this sample, followed by clinopyroxene, hornblende, and Fe-Ti oxide microphenocryst. Resorbed interior is found common in plagioclase phenocryst. The groundmass is mainly composed of minute crystals of clinopyroxene and plagioclase. The hornblende phenocryst shows both black Fe-oxide rim and clinopy- 


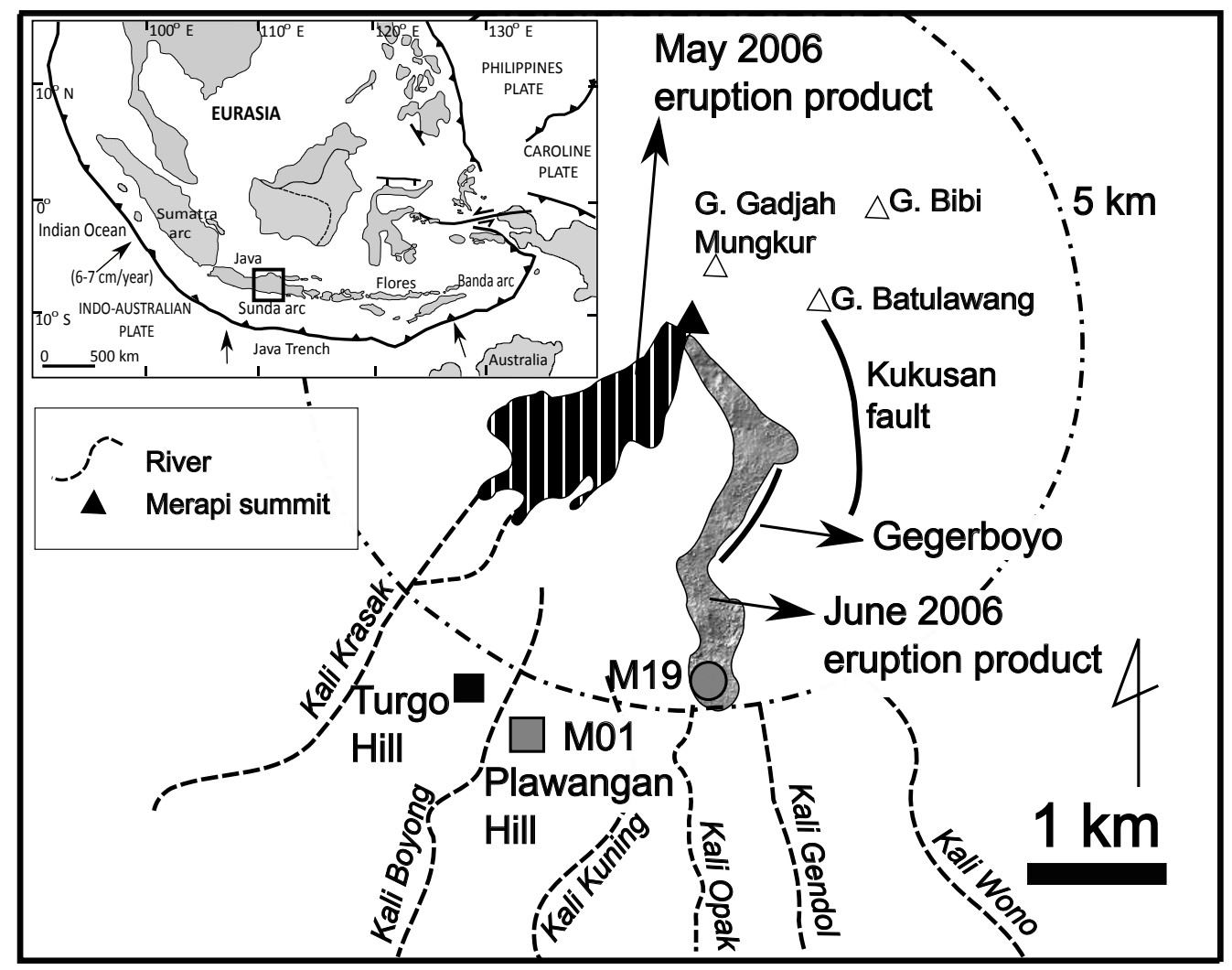

Figure 1: Sampling location. Delineated May and June 2006 eruption product distribution is modified from Charbonnier and Gertisser (2008). G stands for Gunung, an Indonesian word for mountain. Kali is an Indonesian word for river.

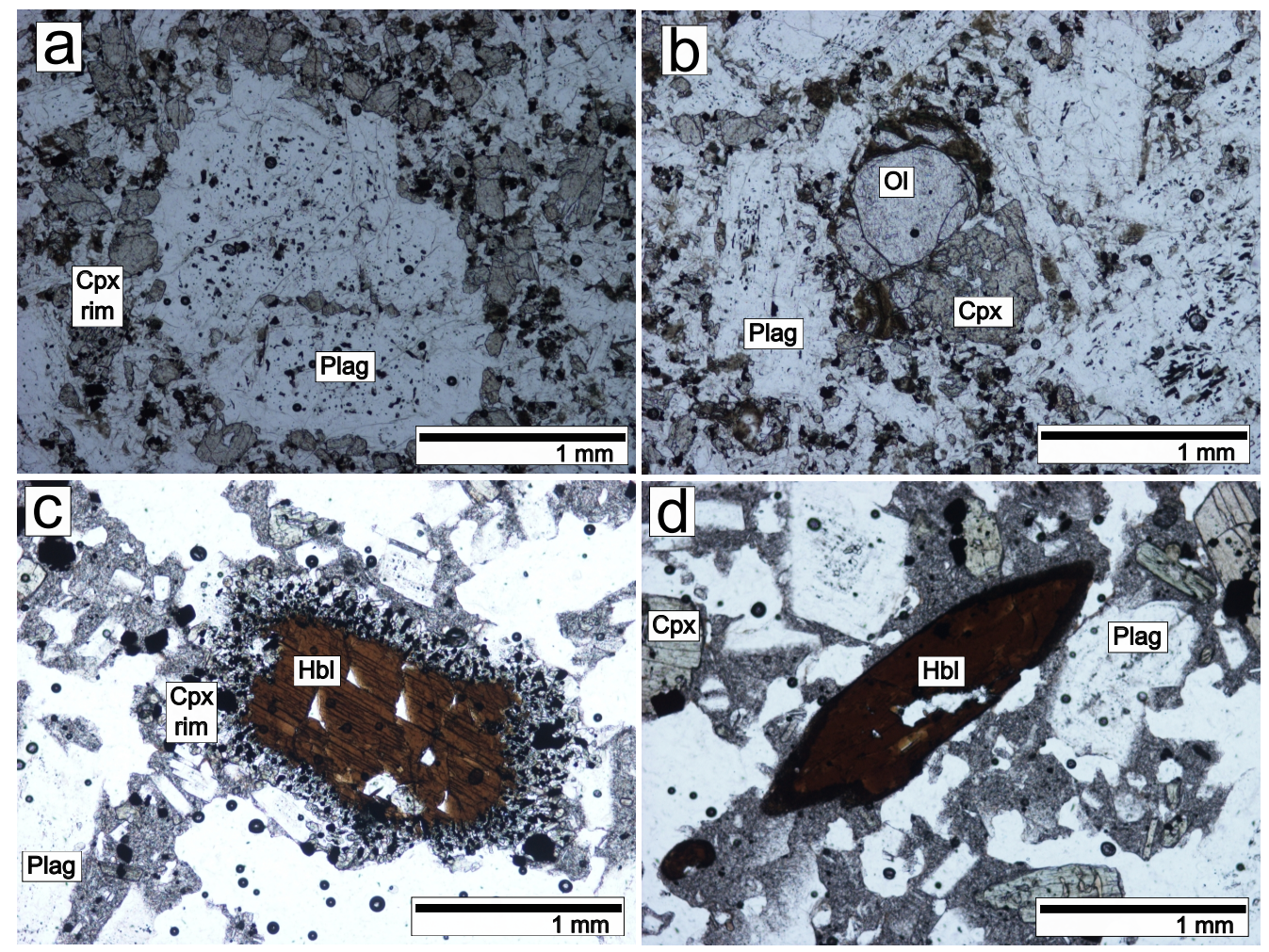

Figure 2: Thin section photomicrographs of Plawangan Hill sample ( $a$ and b) and Kaliadem 2006 eruption sample (c and $\mathrm{d}$ ). All photos are in plane polarized view. Cpx = clinopyroxene; Plag = plagioclase; $\mathrm{Ol}=$ olivine; $\mathrm{Hbl}=$ hornblende. 
roxene microphenocryst rim (Figure $2 \mathrm{c}$ and 2d).

\section{Major and trace elements}

The two samples from Plawangan Hill and 2006 eruption juvenile are plotted within the trends observed by Gertisser and Keller (2003b). The $\mathrm{SiO}_{2}$ versus $\mathrm{K}_{2} \mathrm{O}$ plot (Figure 3) shows that sample from Plawangan is plotted in high-K calcalkaline field and is in linear trend with highK series, while 2006 eruption sample is plotted within medium-K series trend described in Gertisser and Keller (2003b). Most of the medium$\mathrm{K}$ series samples are basaltic andesite in composition. Their $\mathrm{SiO}_{2}$ content is predominantly greater than $54 \mathrm{wt} . \%$, except for one basaltic sample. On the other hand, samples form high$\mathrm{K}$ series fall in a wide range of $\mathrm{SiO}_{2}$ and extend to basaltic compositions.

Major element variation diagram is summarized in Figure 4. Olivine basalt lava from Plawangan tends to be plotted in the lowest end of $\mathrm{SiO}_{2}$ content. This lava sample, however, has lower $\mathrm{MgO}, \mathrm{Cr}$, and Ni contents (4.47 wt.\%, $65 \mathrm{ppm}$, and $27 \mathrm{ppm}$, respectively) than typical unfractionated magma, indicating a readily fractionated magma. Distinctive separated trend of both magma series is only apparent in $\mathrm{SiO}_{2}$ vs $\mathrm{K}_{2} \mathrm{O}$ plot. Plots of $\mathrm{SiO}_{2}$ versus other trace elements show a rather mixed trend. A detailed look into $\mathrm{SiO}_{2}$ versus $\mathrm{TiO}_{2}$ suggests a slight separate trend of both series which shows that for similar $\mathrm{SiO}_{2}$ content, slightly higher $\mathrm{TiO}_{2}$ is observed in medium-K samples than in high-K samples. $\mathrm{Al}_{2} \mathrm{O}_{3}$ is scattered in all samples and shows no apparent correlation with $\mathrm{SiO}_{2}$. The observed separate trend of $\mathrm{MgO}$ and $\mathrm{Fe}_{2} \mathrm{O}_{3}$ in high- $\mathrm{K}$ basalt is negligible considering the distribution of other samples from this series.

Trace element variation diagram in Figure 5 largely shows obscure trend as $\mathrm{SiO}_{2}$ increases, except for $\mathrm{Ba}, \mathrm{Pb}$, and $\mathrm{Sr}$ which show possible increasing trend in both series. Samples with $\mathrm{B}$ concentration do not provide observable trend. However, B in 2006 eruption sample is higher than that from Plawangan Hill sample. Ni contents of shown samples display unclear trend and are all smaller than $5 \mathrm{ppm}$, except for Plawangan Hill sample (27 ppm). Other HFS elements (High Field Strength), including La, Nb, and $Y$, also show similar range of values and lack of apparent trend in both series.

\section{Discussion}

Gertisser and Keller (2003b) suggest that both medium-K and high- $\mathrm{K}$ series from Merapi are independent of shallow processes such as fractional crystallization and crustal contamination despite the lack of primary magma composition. Similar assumption is also applicable to the two selected samples which are basalt (M01) and basaltic andesite (M19) in composition, since they are both geochemically well fitted to each series. Gertisser and Keller (2003b) also strongly suggest that both series are produced by different level of source contamination by subducting sediment as well displayed by radiogenic isotopes of the samples. They further argue that medium-K magma series (older than 1900 years) show lower input of subducting sediment than high-K magma series (younger than 1900 years).

All rock series from Merapi, including both Plawangan lava and 2006 eruption juvenile, show similar range of immobile element ratios $(\mathrm{Zr} / \mathrm{Nb}, \mathrm{Nb} / \mathrm{Y})$ within a wide range of fluid mobile element/HFSE ratio (Figure 7), suggesting a homogeneous mantle source prior to modification by slab derived components. Indian Ocean Mid Oceanic Ridge Basalt (IMORB) has been introduced as a sub-arc mantle source beneath Sunda arc (e.g., Gertisser and Keller, 2003b; Handley et al., 2007; Sendjaja et al., 2009; Handley et al., 2011; Gertisser et al., 2012). A wide range of IMORB composition has been reported by Chauvel and Blichert-Toft (2001). Figure 6 and Figure 7 suggest that a depleted IMORB (low $\mathrm{Zr} / \mathrm{Nb}$ and $\mathrm{Nb} / \mathrm{Y}$ ratios, plotted on the left side of range of mantle compositional variations) might have been the potential mantle source compared to others. The composition of this mantle source is given in Table 2.

Plawangan lava and 2006 eruption juvenile, and both medium-K and high-K series, show $\mathrm{Nb}$ negative anomaly, a typical characteristic of island arc magmas (Figure 6). This figure also suggests that these samples are all showing similar range of LILE and HFSE enrichments compared to primitive mantle, indicating that the two series are not produced by different degree of partial melting of a similar man- 


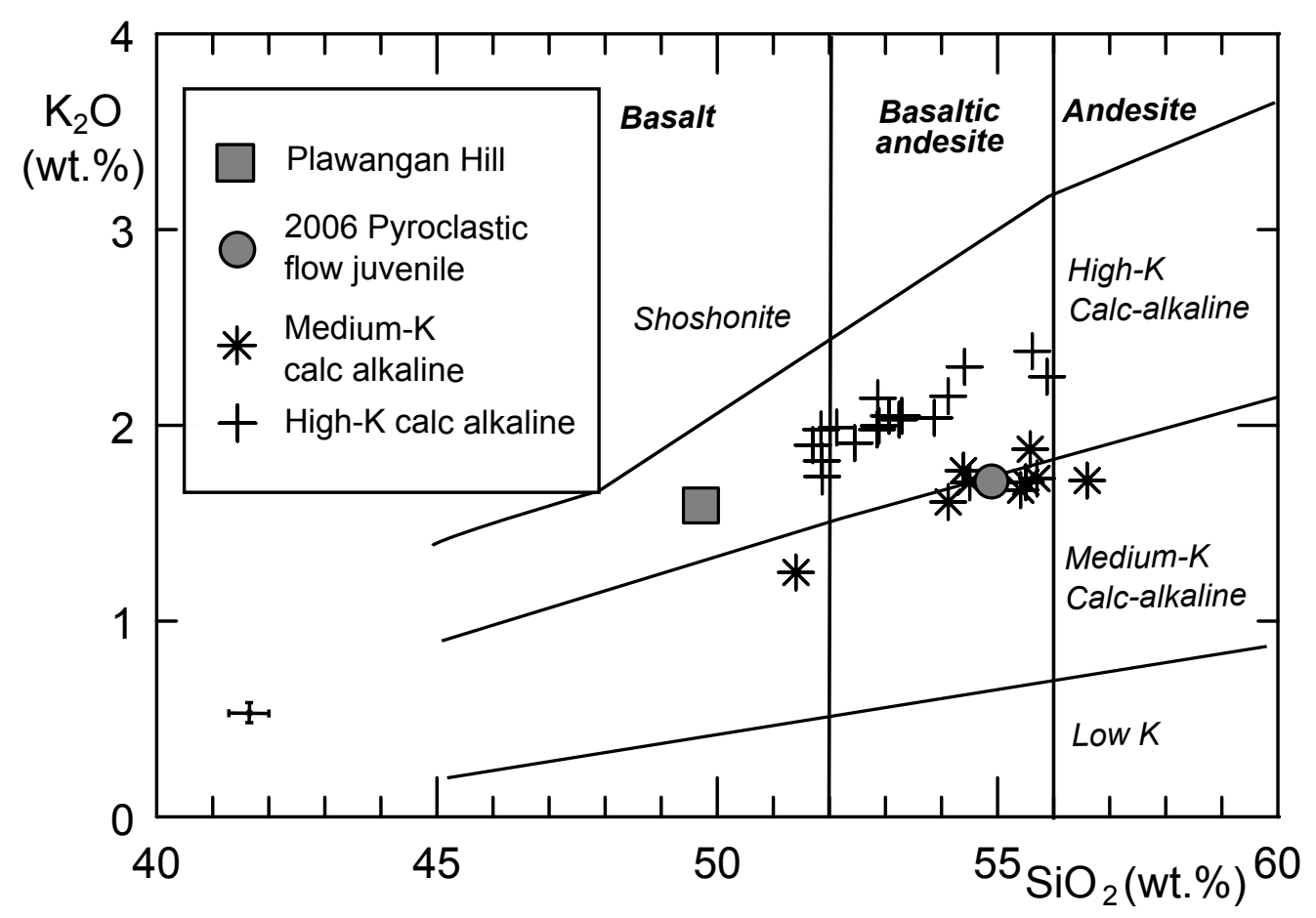

Figure 3: Plot of $\mathrm{SiO}_{2}$ vs $\mathrm{K}_{2} \mathrm{O}$. High-K and medium-K calc alkaline samples from Merapi is from Gertisser and Keller (2003b). Error bar represents calculated standard error. See text for explanation. The same explanation goes to error bar in Figure 4 and Figure 5.

tle source. Range of these magma compositions can be produced by $20 \%$ to $30 \%$ partial melting of the depleted IMORB mantle source (Figure 6). A detailed look on $\mathrm{Pb}$ enrichment of these samples suggests a strong influence from SED since the potential candidates for the subducting sediments are all enriched in $\mathrm{Pb}$ (light shaded area in Figure 6). The partial melting of depleted IMORB alone, however, is inadequate to produce $\mathrm{B}, \mathrm{Ba}$, and $\mathrm{Pb}$ enrichment in all magma series from this study.

Fluid mobile elements to HFSE ratios suggest initial variation of slab-derived component in both magma series is existent. The changes of slab-derived component, however, might have not been restricted to samples which were erupted prior to and over the past 1900 years. Plawangan lava sample, together with other high-K samples, have shown higher ratios of fluid mobile element/HFSE (i.e. $\mathrm{B} / \mathrm{Nb}, \mathrm{Ba} / \mathrm{Nb}$, $\mathrm{Pb} / \mathrm{Nb}$, Figure 7) than 2006 eruption juvenile and other medium-K samples. Similar fluid mobile element to $\mathrm{Y}$ ratios, however, display a less certain gap between both samples and series.

The model shown in Figure 8 suggests a more detailed estimation of slab derived fluids from both AOC and SED to Merapi through the evolution of both magma series. This model assumes that the slab components are all transferred from the subdcuting slab to the mantle wedge during slab dehydration. The model uses the ability of the element to freely move in fluid phase, defined as mobility (M) in Sano et al. (2001). The mobility of each element will determine their abundance in fluid derived from both AOC and SED. The mobility of B, $\mathrm{Ba}$, and $\mathrm{Nb}$ during dehydration was estimated from high-pressure experiments by Brenan et al. (1995), Johnson and Plank (1999), and Aizawa et al. (1999). The concentration of these element in fluids derived from dehydrated slab is calculated following Sano et al. (2001) assuming $1.5 \%$ of hydrous fluid extraction (Tatsumi and Kogiso, 1997; Kogiso et al., 1997; Sano et al., 2001). The equation is $C_{f}=C_{0} \times M / F$, where $C_{0}$ is the original content, $M$ is mobility, and $F$ is extracted hydrous fluid. The end member used in Figure 8 is provided in Table 2.

Figure 8 shows that B and Ba contents of samples from all series, including Plawangan lava and 2006 eruption juvenile, are generated by addition of a total slab derived fluid at $5 \%$ and $14 \%$, respectively. The high-K samples 


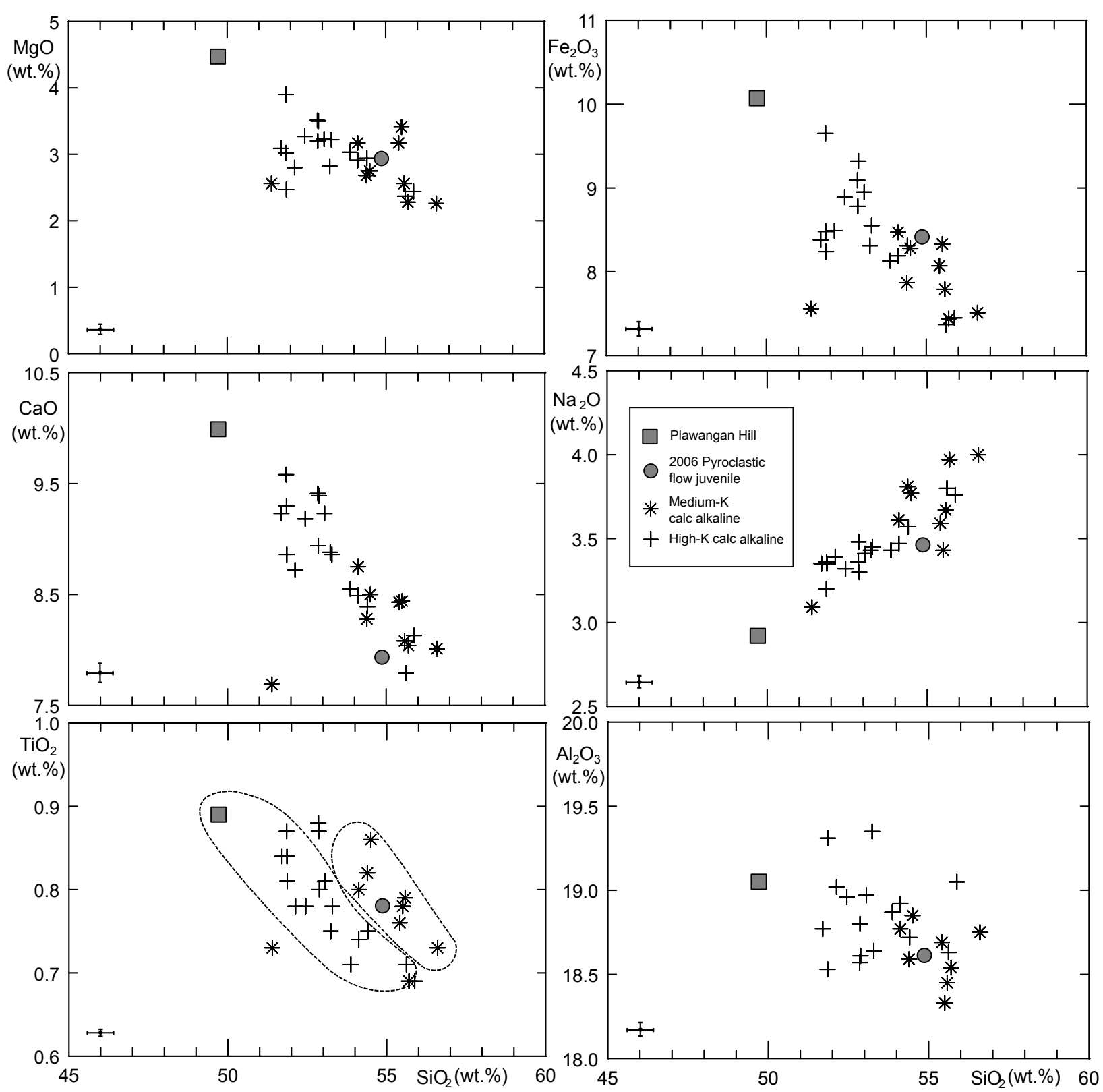

Figure 4: Major element variation diagram. 

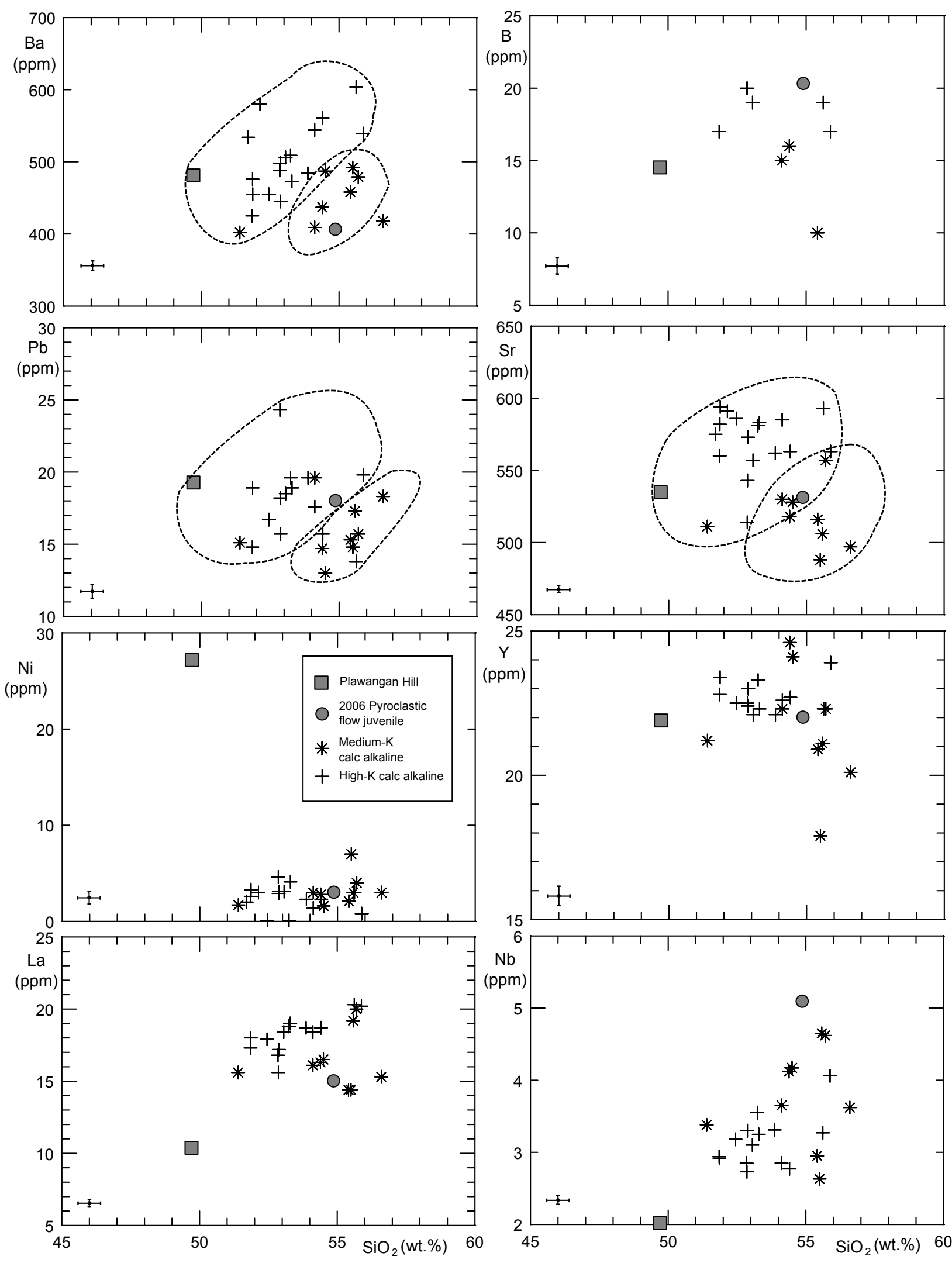

Figure 5: Trace element variation diagram. 


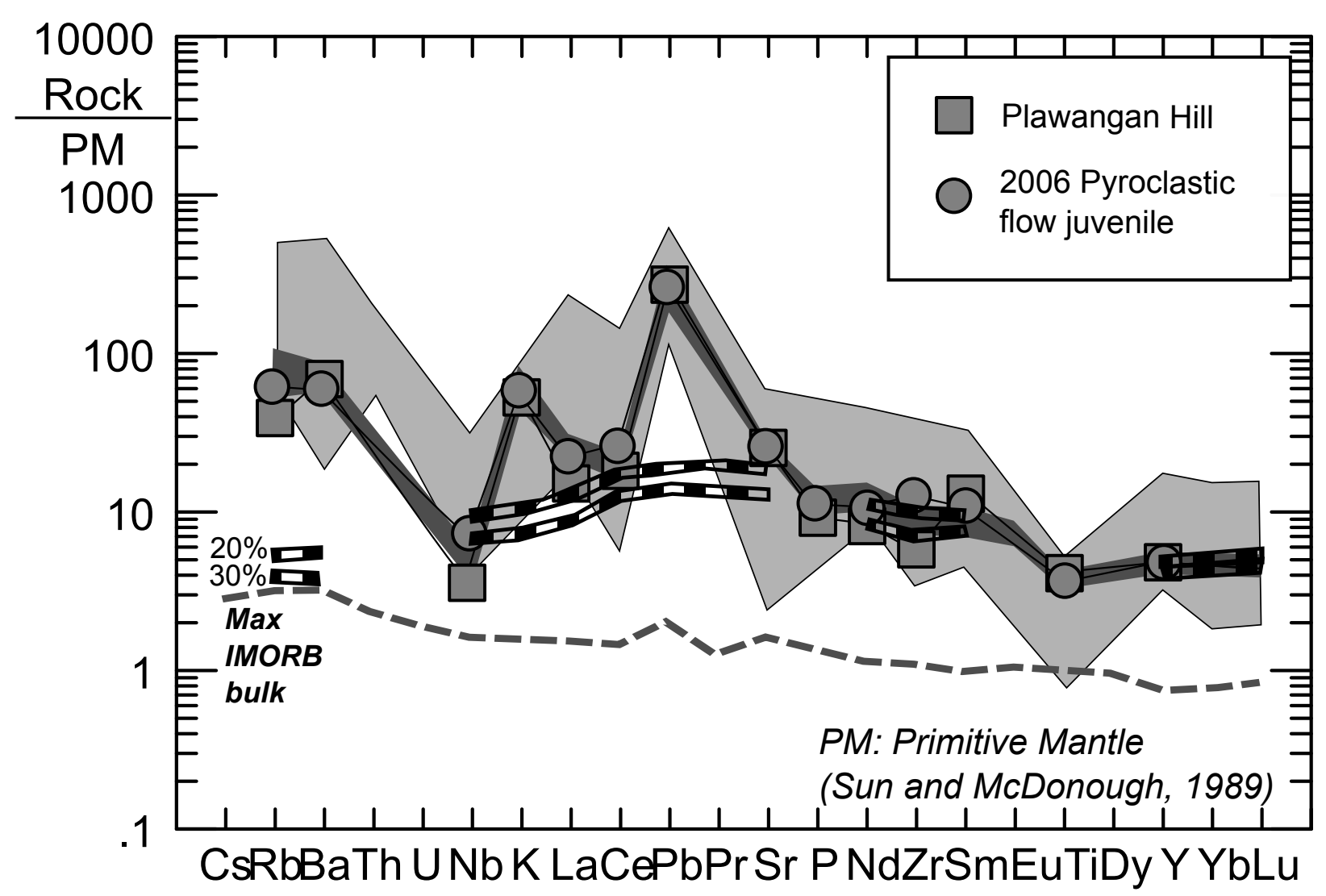

Figure 6: Spidergram of Merapi samples normalized to Primitive Mantle (PM composition is after Sun and McDonough, 1989). Dark shaded area is High-K and Medium-K calc alkaline samples from Merapi defined in Gertisser and Keller (2003b). Light shaded area is collection of bulk sediment from Indian Ocean (Ben Othman et al., 1989). Maximum bulk Indian Ocean MORB (IMORB) is from Chauvel and Blichert-Toft (2001). The melting of IMORB is simulated assuming the source composition has olivine, orthopyroxene, clinopyroxene, and spinel (60:30:25:5). Black striped lines represent $30 \%$ and $20 \%$ partial melting of the depleted IMORB (dIMORB) presented in Table 2. Melting is calculated using Batch melting equation $C_{\mathrm{L}} / C_{0}=1 /[D+F(1-D)]$. 

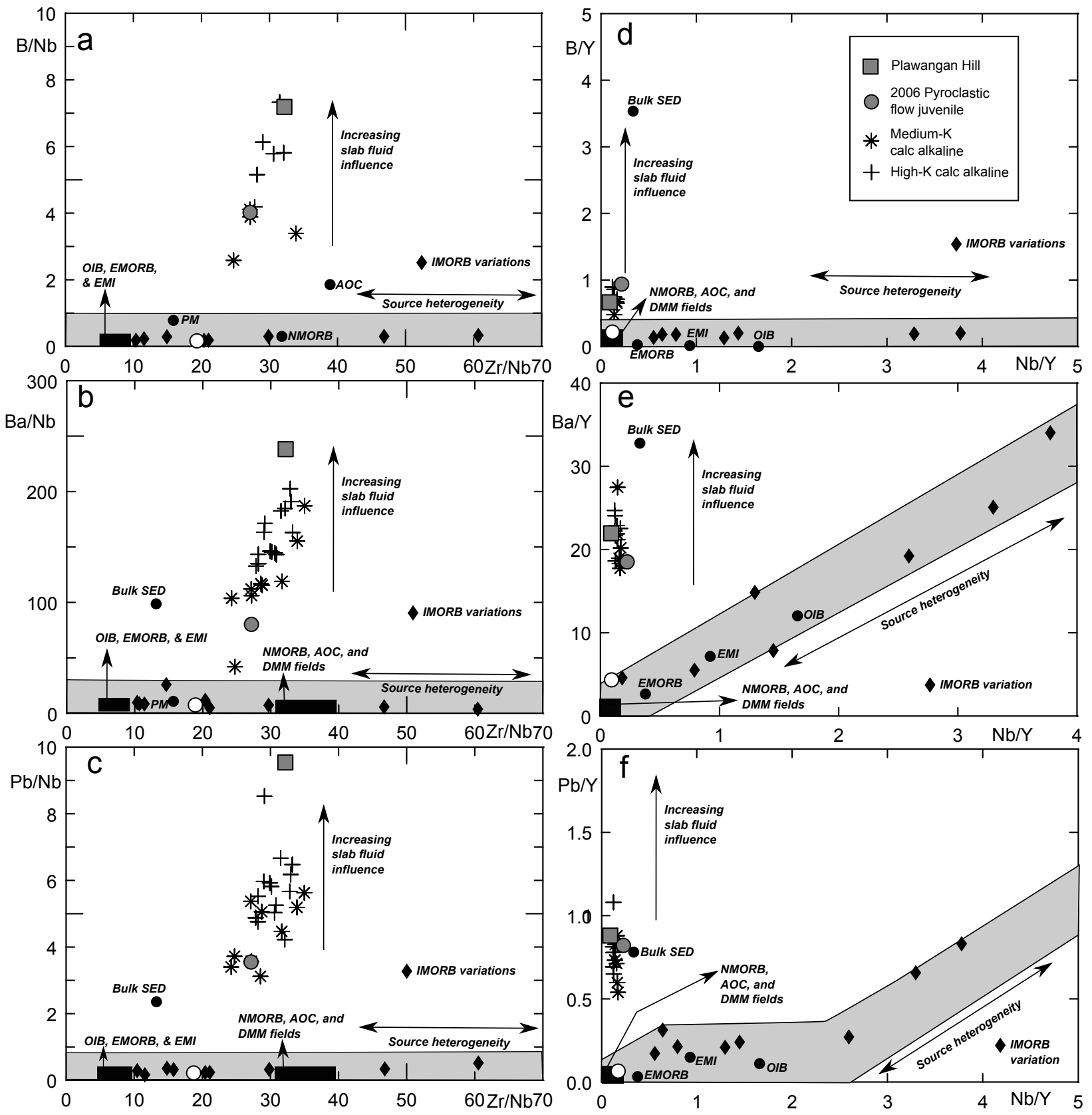

Figure 7: Trace element ratio plots. Shaded area shows the range of mantle source composition. NMORB, EMORB, OIB, DMM, and EMI are from Sun and McDonough (1989). IMORB variation is from Chauvel and Blichert-toft (2001). Bulk sediment is from Ben Othman et al. (1989). AOC is AOC bulk from site 215 (Thompson et al., 1974). Selected end members are listed in Table 2. White circle represents the projected ideal dIMORB mantle source for Merapi magmas. 


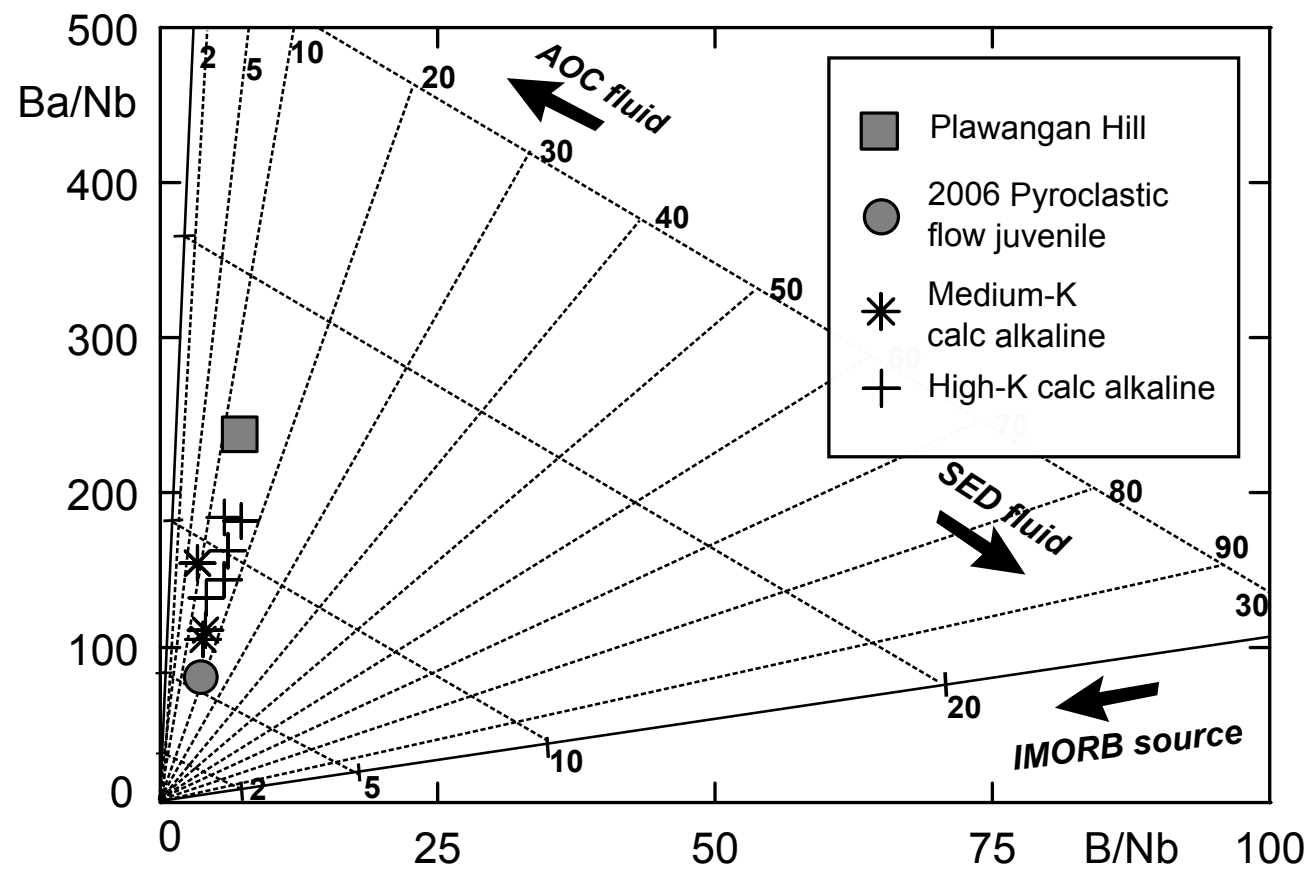

Figure 8: Plot of $\mathrm{B} / \mathrm{Nb}$ versus $\mathrm{Ba} / \mathrm{Nb}$. Dotted lines are the ratios between the fluids derived from marine sediment (SED) to fluids derived from altered oceanic crust (AOC). End members used is similar to Figure 8. See text for details.

and Plawangan lava require greater addition of total slab derived fluid to explain its $B$ and Ba compositions than the medium-K samples and 2006 eruption juvenile. A detailed look explains that samples from all series received fluids from both SED and AOC at 10:90 and 20:80 ratios (SED:AOC). The ratio quantifies addition of $1.5 \%$ SED derived fluid (11\% of $14 \%$ total slab fluid) to Plawangan magma and $1.2 \%$ SED derived fluid (20\% of $6 \%$ total slab fluid) to 2006 eruption magma. The same model also estimates that high-K magma receives sediment fluid contribution within the range of 1.4 to $1.7 \%$, higher than medium-K magma which receives 0.9 to $1.1 \%$ of sediment derived fluid. This confirms Gertisser and Keller (2003b) that sediment contribution is increasing in Merapi volcanic products younger than 1900 series.

This result is in agreement with estimation using isotopic ratios which suggests $~ 1-2 \%$ sediment contribution to both series of Merapi magmas (Gertisser and Keller, 2003b). The same quantification suggests that AOC fluid decreases from $12 \%$ in Plawangan magma to $4.8 \%$ in magma erupting in 2006. The SED:AOC ratio is consistent regardless of the type of subducting sediment, as long as it has high Ba content in bulk sediment. AOC from
DSDP site 215, which has high-Ba basalts and altered basalts, is required to generate a consistent SED:AOC ratio. The weakness of this $\mathrm{B} / \mathrm{Nb}$ versus $\mathrm{Ba} / \mathrm{Nb}$ plot is that the estimation of SED and AOC fluids contribution is not straightforward. This plot, however, provides a contrast that displays abundance of B in SED derived fluid and of $\mathrm{Ba}$ in $\mathrm{AOC}$ derived fluid. This clear division allows the prediction of both AOC and SED at the same time.

This result suggests that the changes of slab derived fluids may not always be one directional event and linear with time. The evidence that slab derived fluid is high in Ancient Merapi magma and is low in Modern Merapi magma widen the perspective from previous study that suggests the younger product of Holocene eruptions in Merapi (younger than 1900 years) is receiving greater sediment derived supplies than the products older than 1900 years. This calls for further question of (1) how fast slab input changes over time and (2) what causes a seemingly sudden changes of slab input to the mantle wedge. One possible explanation for this rapid fluctuation of slab components in magmas from one volcano is veined mantle model. In this model, sub-arc mantle that suffers from hydrous metasoma- 
Table 2: Composition of end member used in model.

\begin{tabular}{lccc}
\hline & AOC $^{\mathrm{a}}$ & SED $^{\mathrm{b}}$ & dIMORB $^{\mathrm{c}}$ \\
\hline \multicolumn{2}{c}{ (wt.\%) } \\
$\mathrm{K}_{2} \mathrm{O}$ & 0.62 & 2.5 & 0.07 \\
$\mathrm{TiO}_{2}$ & 1.7 & 0.71 & 1.5 \\
& \multicolumn{2}{c}{ ppm $^{2}$} & \\
$\mathrm{~B}$ & 5.2 & 115 & 0.5 \\
$\mathrm{Rb}$ & 14 & 82 & 0.56 \\
$\mathrm{Ba}$ & 15.6 & 1068 & 6.5 \\
$\mathrm{Th}$ & 0.17 & 9.78 & 0.12 \\
$\mathrm{Nb}$ & 2.89 & 10.92 & 1.6 \\
$\mathrm{La}$ & 3.4 & 39.08 & 1.92 \\
$\mathrm{Ce}$ & 11.4 & 86.08 & 7.5 \\
$\mathrm{~Pb}$ & 0.44 & 25.5 & 0.3 \\
$\mathrm{Sr}$ & 180 & 218 & 90 \\
$\mathrm{Nd}$ & 6.68 & 34 & 4.3 \\
$\mathrm{Sm}$ & 3.95 & 7.06 & 1.3 \\
$\mathrm{Zr}$ & 112 & 145 & 29 \\
$\mathrm{Eu}$ & 1.34 & 1.43 & 0.54 \\
$\mathrm{Y}$ & 41 & 33 & 9 \\
$\mathrm{Yb}$ & 4.02 & 3.24 & 0.98 \\
$\mathrm{Lu}$ & & & 0.16 \\
\hline $\mathrm{a}$ & & &
\end{tabular}

a AOC is altered oceanic crust from DSDP Leg 22, site 215 (Thompson et al., 1974), except B is from Smith et al. (1995).

b SED is selected sediment from Ben Othman et al. (1989).

c dIMORB is depleted IMORB, modified from IMORB values in Chauvel and Blichert-Toft (2001).

tism instigated by addition of slab-derived fluid may display veins that are more enriched in slab-derived fluid components (Kepezhinskas and Defant, 1996; Szabó et al., 1996; Demeny et al., 2004; Halama et al., 2009). Partial melting of the enriched veins in the mantle may increase slab signature in the arc magmas (Grégoire et al., 2001). Random melting of the veined mantle, therefore, may result in fluctuation of slab components observed in the course of magma evolution in a volcano.

\section{CONCLUSION}

Gertisser and Keller (2003b) have shown that Holocene Merapi has erupted both medium-K series and high-K series which requires higher input of subducting sediment in the latter than in the former. The high-K series is exclusive to samples younger than 1900 years, as the medium-K series is exclusive to samples older than 1900 years. The evidence that Plawangan lava has higher ratio of fluid mobile ele-
ment/HFSE (i.e. B/ Nb, Ba/Nb, $\mathrm{Pb} / \mathrm{Nb}$ ) may suggest that the slab derived component was, at least once, high during the development of Ancient Merapi. In contrast, the low ratio of the same elements in 2006 eruption juveline, compared to Plawangan lava, suggests that Modern Merapi may also produce magma with low slab derived component.

The model using $\mathrm{B} / \mathrm{Nb}$ versus $\mathrm{Ba} / \mathrm{Nb}$ details the addition of $1.5 \%$ and $1.2 \%$ of SED fluid to Plawangan magma and 2006 eruption magma respectively. Despite the close affinities of Plawangan lava to high-K series and 2006 eruption juvenile to medium-K series, this model suggests that the mantle source of Ancient Merapi might have been received greater contribution of slab derived fluid contribution than that of Modern Merapi. This finding suggests that the fluctuation of slab derived flux may take a shorter time than it is expected. It is however still unknown what controls the changes of slab derived fluid flux in a relatively short period of geologic time. One possible explanation for this rapid fluctuation of slabderived fluid is veined hydrous metasomatized mantle beneath Merapi volcano. This model allows some areas of the mantle, mainly in the form of veins, to be more enriched in slab components than the rest. Random melting of this mantle type enables fluctuation of slab components in magmas from one volcano during its evolutional course.

\section{ACKNOWLEDGEMENTS}

We thank H. Matsue, H. Sawahata, and M. Ishimoto for their assistance in organizing the Prompt Gamma-ray Analysis (PGA) at the Japan Atomic Energy Agency (JAEA). The authors also thank Dr. F. Anggara for the help during fieldwork in 2010. We also thank Dr. T. Sano for reviewing the manuscript, providing us valuable input on the earlier version of the manuscript. This work was supported by the Inter-University Program for the Joint Use of JAEA Facilities and by a Grant-in-aid for scientific research (25400491) from the Japan Society for the Promotion of Science, awarded to T. Hasenaka.

\section{REFERENCES}

Aizawa, Y., Tatsumi, Y. and Yamada, H. (1999) Element transport by dehydration of subducted sed- 
iments Implication for arc and ocean island magmatism. Island Arc 8: 38-46.

Andreastuti, S.D. (1999) Stratigraphy and geochemistry of Merapi Volcano, Central Java, Indonesia: implication for assessment of volcanic hazard. Ph.D. thesis, University of Auckland, New Zealand.

Bahar, I. (1984) Contribution à la connaissance du volcanisme Indonésien: Le Merapi (Centre Java), cadre structural, pétrologie, géochemie et implications volcanologiques. Thèse Doct. III ème cycle, Univ. de Motpellier, 213 pp.

Bebout, G.E., Ryan, J.G., Leeman, W.R. and Bebout, A.E. (1999) Fractionation of trace elements by subduction-zone metamorphism: Effect of convergent-margin thermal evolution. Earth and Planetary Science Letters 171: 63-81.

Ben Othman, D., White, W.M. and Patchett, J. (1989) The geochemistry of marine sediments, island arc magma genesis and crust-mantle recycling. Earth and Planetary Science Letters 94: 1-21.

Bhertommier, P. (1990) Etude volcanologique du Merapi (Centre Java). Téphrostratigraphie et Chrologie. Mécanismes éruptifs. Thèse Doct. III ème cycle, Univ. Blaise Pascal, Clermont-Ferrand, $115 \mathrm{pp}$.

Boekhold van. (1972) Relaasvan een toght naar den Bradenden berg op Java (den Merapi) 17/18 juli 1786 en 9/10 augustus 1786. Bataav. Genoot. Verh. 6: 8-17

Brenan, J.M., Shaw, H.F., Ryerson, F.J. and Phinney, D.L. (1995) Mineral-aqueous fluid partition of trace elements at 9008C and 2.0 GPa: Constraints on the trace element chemistry of mantle and deep crustal fluids. Geochimica Cosmochimica Acta 59: 3331-3350.

Camus, G., Gourgaud, A., Mossand-Bhertommier, P.-C. and Vincent, P.M. (2000) Merapi (Central Java, Indonesia): an outline of the structural and magmatological evolution, with a special emphasis to the major pyroclastic events. Journal of Volcanology and Geothermal Research 100: 139-163.

Charbonnier, S. and Gertisser, R. (2008) Field observations and surface characteristics of pristine block-and-ash flow deposits from the 2006 eruption of Merapi volcano, Java, Indonesia. Journal of Volcanology and Geothermal Research 177: 971-982.

Chauvel, C. And Blichert-Toft, J. (2001) A hafnium isotope and trace element perspective on melting of the depleted mantle. Earth and Planetary Science Letters 190: 137-151.

Elliott, T. (2003) Tracers of the slab. In: Inside the subduction factory. Geophysical Monograph, 138.

Gertisser, R. and Keller, J. (2003a) Temporal variations in magma composition at Merapi volcano (Central Java, Indonesia): magmatic cycles dur- ing the past 2000 years of explosive activity. Journal of Volcanology and Geothermal Research 123: 1-23.

Gertisser, R. and Keller, J. (2003b) Trace element and $\mathrm{Sr}, \mathrm{Nd}, \mathrm{Pb}$ and $\mathrm{O}$ isotope variations in medium$\mathrm{K}$ and high-K volcanic rocks from Merapi volcano, Central Java, Indonesia: evidence for the involvement of subducted sediments in Sunda arc magma genesis. Journal of Petrology 44: 457-489.

Gertisser, R., Self, S., Thomas, L.E., Handley, H.K., Calsteren, P.V. and Wolff, J.A. (2012) Process and timescales of magma genesis and differentiation leading to the great Tambora eruption in 1815. Journal of Petrology 53: 271-297.

Handley, H.K., Macpherson, C.G., Davidson, J.P., Berlo, K. and Lowry, D. (2007) Constraining fluid and sediment contributions to subduction-related magmatism in Indonesia: Ijen volcanic complex. Journal of Petrology 48: 1155-1183.

Handley, H.K., Turner, S., Macpherson, C.G., Gertisser, R. and Davidson, J.P. (2011) Hf-Nd isotope and trace element constraints on subduction inputs at island arcs: limitations of $\mathrm{Hf}$ anomalies as sediment input indicators. Earth and Planetary Science Letters 304: 212-223.

Hanyu, T., Gill, J., Tatsumi, Y., Kimura, J-I., Sato, K., Chang, Q., Senda, R., Miyazaki, T., Hirahara, Y. and Takahashi, T. (2012) Across- and along-arc geochemical variations of lava chemistry in the Sangihe arc: Various fluid and melt slab fluxes in response to slab temperature. Geochemistry Geophysics Geosystems, 13, 10.

Ishikawa, T. and Nakamura, E. (1993) Boron isotope systematics of marine sediments. Earth and Planetary Science Letters 117: 567-580.

Ishikawa, T. and Nakamura, E. (1994) Origin of the slab component in arc lavas from across-arc variation of $\mathrm{B}$ and $\mathrm{Pb}$ isotopes. Nature 370: 205-208.

Johnson, M.C. and Plank, T. (1999) Dehydration and melting experiments constrain the fate of subducted sediments. Geochemistry Geophysics Geosystems, 1.

Kogiso, T., Tatsumi, Y. and Nakao, S. (1997) Trace element transport during dehydration processes in the subducted oceanic crust: 1. Experiments and implications for the origin of ocean island basalts. Earth and Planetary Science Letters 148: 193-205.

Moran, A.E., Sisson, V.B. and Leeman, W.P. (1992) Boron depletion during progressive metamorphism: implications for subdution processes. Earth and Planetary Science Letters 111: 331-349.

Mori, Y. and Mashima, H. (2005) X-ray fluorescence analysis of major and trace elements in silicate rocks using 1:5 dilution glass beads. Bulletin of Kitakyushu Museum of Natural History and $\mathrm{Hu}-$ man History, Series A3, 1-12.

Morris, J.D., Leeman, W.P. and Tera, F. (1990). The subducted component in island arc lavas: Con- 
straints from Be isotopes and B-Be systematics. Nature 344: 31-36.

Newhall, C.G., Bronto, S., Alloway, B., Banks, N.G., Bahar, I., del Marmol, M.A., Hadisantono, R.D., Holcomb, R.T., McGeehin, J., Miksic, J.N., Rubin, M., Sayudi, S.D., Sukhyar, R., Andreastuti, S., Tilling, R.I., Torley, R., Trimble, D. and Wirakusumah, A.D. (2000) 10,000 Years of explosive eruptions of Merapi Volcano, Central Java, archaeological and modern implications. Journal of Volcanological and Geothermal Research 100: 9-50

Pearce, J.A., Stern, R.J., Bloomer, S.H. and Fryer, P. (2005) Geochemical mapping of the Mariana arc-bassin system: implications for the nature and distribution of subduction components. Geochemistry Geophysics Geosystems, 6 .

Ratdomopurbo, A., Beauducel, F., subandriyo, J., Nandaka, I.G.M.A., Newhall, C.G., Suharna, Sayudi, D.S., Suparwaka, H. and Sunarta. (2013) Overview of the 2006 eruption of Mt. Merapi. Journal of Volcanological and Geothermal Research 261: 87-97.

Ryan, J.G., Morris, J.D., Tera, F., Leeman, W.P. and Tsvetkov, A. (1995) Cross-arc geochemical variations in the Kurile arc as a function of slab depth. Science 270: 625-627.

Sano, T., Fukuoka, T., Hasenaka, T., Yonezawa, C., Matsue, H. and Sawahata, H. (1999) Accurate and efficient determination of boron content in volcanic rocks by neutron induced prompt gammaray analysis. Journal of Radioanalitycal and $\mathrm{Nu}-$ clear Chemistry 239: 613-617.

Sano, T., Hasenaka, T., Shimaoka, A., Yonezawa, C. and Fukuoka, T. (2001) Boron contents of Japan trench sediments and Iwate basaltic lavas, Northeast Japan arc: estimation of sediment-derived fluid contribution in mantle wedge. Earth and Planetary Science Letters 186: 187-198.

Sano, T., Fukuoka, T. and Hasenaka, T. (2004) Determination of chlorine contents in Geological Survey of Japan reference materials by prompt gamma neutron activation analysis. Geostandard and Geoanalysis Research 28: 443-448.

Sendjaja, Y.A., Kimura, J. and Sunardi, E. (2009) Across-arc geochemical variation of Quaternary lavas in West Java, Indonesia: Mass-balance elucidation using arc basalt simulator model. Island Arc 18: 201-224.

Smith, H.J., Spivack, A.J., Staudigel, H. and Hart, S.R. (1995) The boron isotopic composition of altered oceanic crust. Chemical Geology 126: 119135.
Sun, S.S. and McDonough, W.F. (1989) Chemical and isotopic systematics of oceanic basalts: implications for mantle composition and processes. In: Saunders AD, Norry MJ (eds) Magmatism in the ocean basins. Geological Society Special Publication 42: 313-345.

Tatsumi, Y. and Kogiso, T. (1997) Trace element transport during dehydration processes in the subducted oceanic crust: 2 . Origin of chemical and physical characteristics in arc magmatism. Earth and Planetary Science Letters 148: 207-221.

Tera, F., Brown, L., Morris, J., Sacks, I.S., Klein, J. and Middleton, R. (1986) Sediment incorporation in island arc magmas: inference from ${ }^{10} \mathrm{Be}$. Geochimica et Cosmochimica Acta 50: 535-550.

Thompson, G., Bryan, W.B., Frey, F.A. and Sung, C.M. (1974) Petrology and geochemistry of basalts and related rocks from sites 214, 215, 216, DSDP Leg 22, Indian Ocean. Initial Reports Deep Sea Drilling Project 22: 459-468.

Turner, S. and Foden, J. (2001) U, Th and Ra disequilibria, $\mathrm{Sr}, \mathrm{Nd}$ and $\mathrm{Pb}$ isotope and trace element variations in Sunda arc lavas: predominance of a subducted sediment component. Contribution to Mineralogy and Petrology 142: 43-57.

Vroon, P.Z., Lowry, D., Van Bergen, M.J., Boyce, A.J. and Mattey, D.P. (2001) Oxygen isotope systematics of the Banda Arc: low $\mathrm{d}^{18} \mathrm{O}$ despite involvement of subducted continental material in magma genesis. Geochimica et Cosmochimica Acta 65: 589-609.

Vroon, P.Z., Van Bergen, M.J., White, W.M. and Varekamp, J.C. (1993) Sr-Nd-Pb isotope systematics of the Banda arc, Indonesia: combined subduction and assimilation of continental material. Journal of Geophysical Research 98: 22349-22366.

Whitford, D.J. and Jezek, P.A. (1982) Isotopic constraints on the role of subducted sialic material in Indonesian island-arc magmatism. Geological Society of America Bulletin 93: 504-513.

Yonezawa, C., Wood, A.K.H., Hoshi, M., Ito, Y. and Tachikawa, E. (1992) The characteristics of the prompt gamma-ray analyzing system at the neutron beam guides of JRR-3M. Nuclear Instruments and Methods in Physics Research A329: 207-216.

Yonezawa, C. and Wood, A.K.H. (1995) Prompt yray analysis of boron with cold and thermal neutron guide beams. Analytical Chemistry 67: 44664470 . 